\title{
Soil seed bank and community dynamics in an annual-dominated Mediterranean salt-marsh
}

\author{
Marañón, T. \\ Instituto de Recursos Naturales y Agrobiología de Sevilla, C.S.I.C., P.O.Box 1052, E-41080 Sevilla, Spain; \\ Fax+34 5462 4002; E-mail teodoro@irnase.csic.es
}

\begin{abstract}
The seed bank in the soil and litter of an annual grassland in the upper salt marsh of the Guadalquivir delta (SW Spain) contained on average 49110 seeds $/ \mathrm{m}^{2}$; 29 species were represented. Field censuses of the grassland, in two consecutive springs, yielded 7410 and 9520 plants $/ \mathrm{m}^{2}$ respectively. A combined Correspondence Analysis of the seed bank samples and field censuses showed differences in grassland composition between wet and dry years. The environmental changes induced different expressions of the soil seed bank, mediated by demographic processes.

The effect of salinity $(25 \mathrm{dS} / \mathrm{m}$ of $\mathrm{NaCl})$ was studied on intact soil blocks transplanted to a greenhouse. Salinity did not affect the emergence of seedlings, but reduced the growth of the dominant species, Trisetaria panicea.

The importance of the role of seed banks in community dynamics and their use for conservation management are discussed.
\end{abstract}

Keywords: Guadalquivir delta; Mediterranean grassland; Salinity; Seed bank; Transplantation experiment.

Nomenclature: Valdés et al. (1987).

\section{Introduction}

Mediterranean grasslands are mainly composed of annual plants. The predictable summer drought stress has probably favoured this therophyte life form. On the other hand, the rainfall during the growing season is highly variable and unpredictable, inducing striking fluctuations in species composition and abundance (Peco 1989; Figueroa \& Davy 1991).

The soil seed bank forms the basis for this community, which develops anew every autumn. The number of seeds and their germination requirements (e.g. timing and amount of early rains) play a major role in determining the population success and hence the species composition of the grassland (Bartolome 1979; Marañón \& Bartolome 1989; Espigares \& Peco 1993).

Manipulative experiments of soil seed banks, testing different conditions of temperature and moisture during germination, have proved very useful in understanding the species dynamics in annual grasslands (Espigares \&
Peco 1993, 1995). In addition, the transplantation of intact soil blocks, with their buried seed banks, into a greenhouse, allows different environmental conditions to be simulated, and the fate of annual populations during the complete life cycle to be monitored (Marañón \& Bartolome 1993). This latter method is especially appropriate for study sites of low accessibility, such as isolated grassland patches in a seasonally flooded marsh.

The objectives of this study were (1) to estimate the soil seed bank of an annual-dominated upper salt-marsh grassland in the Guadalquivir delta (SW Spain); (2) to relate community dynamics during two subsequent years, in terms of plant density and species richness, to the estimated seed bank; (3) to study the salinity effects on seed bank expression, using transplanted, intact soil blocks.

\section{Material and Methods}

\section{Study area}

The Guadalquivir River delta (SW Spain) contains ca. $1500 \mathrm{~km}^{2}$ of silty-clayey, calcareous and saline soils, derived from fluvio-marine sediments that filled the river estuary during the late Holocene (Clemente et al. in press). The climate is Mediterranean, with cool, wet winters, and warm, dry summers. Mean annual precipitation is $572 \mathrm{~mm}$, mean annual temperature is $18^{\circ} \mathrm{C}$, the coldest month is January with $10^{\circ} \mathrm{C}$ and the warmest month, July with $27^{\circ} \mathrm{C}$ (Marañón et al. 1989b). During the study period, a wet year $(839 \mathrm{~mm}$ of rainfall) was followed by a dry year $(500 \mathrm{~mm}$, see monthly rainfall distribution in Fig. 1).

Persistent flooding and soil salinity are the main environmental factors influencing species composition and abundance of herbaceous communities (García et al. 1993). The study site was located in an upper salt-marsh grassland, $37^{\circ} 00^{\prime} \mathrm{N}, 6^{\circ} 20^{\prime} \mathrm{W}$ (community type 2 in García et al. 1993). These habitats are rarely flooded, and their soil salinity is low to moderate during the growing season (mean EC of soil saturation extract is $4 \mathrm{dS} / \mathrm{m}$ ), rising up slightly during summer droughts (mean EC of $6 \mathrm{dS} / \mathrm{m}$ ).

Scattered chenopod shrubs, Arthrocnemum macro- 


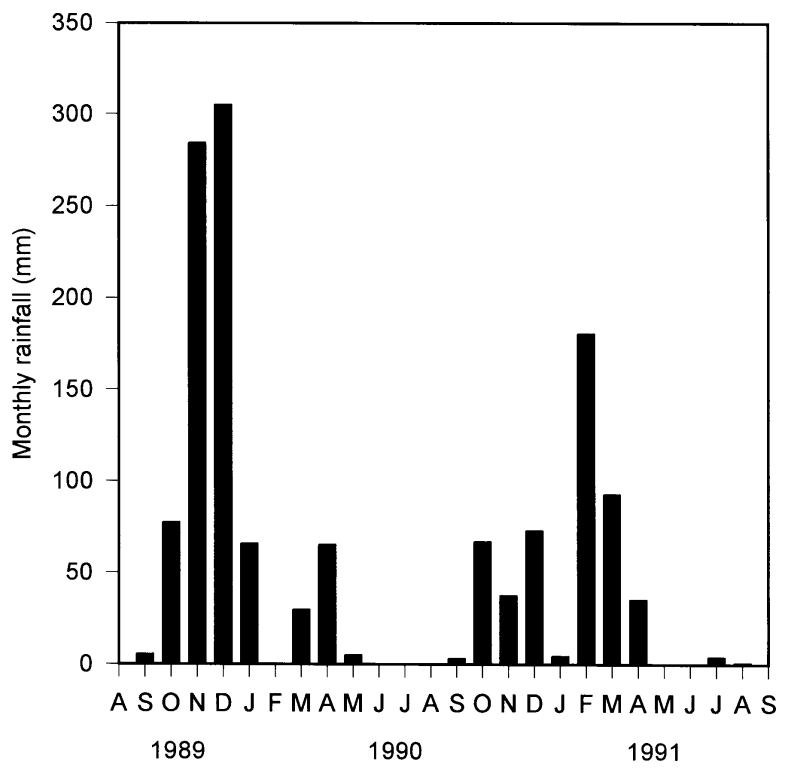

Fig. 1. Monthly distribution of rainfall during the study period. Data are means from the 'Marismilla', 'Brenes' and 'Acebuche' meteorological stations in Doñana National Park.

stachyum and Suaeda vera occur in the grasslands. Free-range domestic animals (ca. 0.05 cow, 0.005 horses and 0.003 sheep per ha) graze the year round (Soriguer et al. 1994).

\section{Soil seed bank sampling}

20 soil samples were collected randomly from a 20 $\mathrm{m} \times 20 \mathrm{~m}$ plot which were located in open grassland without shrubs. Samples were taken with a metal cylinder, with a diameter of $8 \mathrm{~cm}$ and a depth of $4 \mathrm{~cm}$, in September 1989 (before the autumn rains started). Soil samples were stored in paper bags, transported to a greenhouse, crushed, spread in a thin layer of ca. $3 \mathrm{~mm}$ over a siliceous sand substrate of $2 \mathrm{~cm}$ thick, on plastic trays, and watered to keep them moist. Emerging seedlings were identified, counted and then removed from the tray.

After eight months, i.e. in late spring of the following year, watering was interrupted and the soil left to dry. In the following autumn, watering was restarted, the soil samples were stirred to stimulate new germination, and seedlings were identified, counted and discarded during another eight months. The calculated seed bank is the total number of seedlings counted in each soil sample during the two years.

\section{Transplantation experiment}

10 soil blocks of $30 \mathrm{~cm} \times 25 \mathrm{~cm} \times 8 \mathrm{~cm}$ were taken randomly in the same study site, also in September, transported in plastic boxes to the greenhouse and placed, as undisturbed as possible, over a soil container of $55 \mathrm{~cm}$ $\times 80 \mathrm{~cm}$ and $45 \mathrm{~cm}$, filled with sandy soil. Half of the containers were watered regularly with tap water and the other half with a $\mathrm{NaCl}$ solution of $25 \mathrm{dS} / \mathrm{m}(15 \mathrm{~g} / \mathrm{l})$. A permanent wire quadrat of $10 \mathrm{~cm} \times 10 \mathrm{~cm}$ was fixed in the centre of each transplanted soil block and seedlings and plants growing in the quadrat were counted every two weeks. The experiment ran from October to April; then all plants inside the quadrat were clipped at the base, separated individually, oven-dried and weighed.

The significance of the effects of salinity on species richness, plant density and biomass was tested by one-way ANOVA (STATISTICA/w 5.0 program).

\section{Field plant density}

10 quadrats of $10 \mathrm{~cm} \times 10 \mathrm{~cm}$ were randomly located in the same study site, and the plants growing inside were identified and counted the next spring (in March 1990). The measurement of plant density was repeated the following growing season, in April 1991.

For the location of plant density sampling quadrats, random coordinates already used for the samples of soil seed bank or soil blocks were previously excluded, to avoid sampling in disturbed microsites.

\section{Community dynamics}

A combined matrix comprising seed density in 20 soil samples in autumn and plant densities in 10 quadrats for the first and second following springs, was analysed by Correspondence Analysis (CA; Gauch 1982). The species compositions in the seed bank and in the grassland during two years were compared by Sørensen similarity indices (Mueller-Dombois \& Ellenberg 1974).

A second CA analysis was carried out with a combined matrix of the same 20 seed bank samples and the censuses of emerged seedlings and reproductive plants in the 10 quadrats fixed in the transplanted soil blocks subjected to salinity treatment in the greenhouse.

Originally, the program package CANOCO v. 3.12 (ter Braak 1988), with the options of log-transformation of data and downweighting of rare species, was used for both analyses. However, because of the problems with Correspondence Analysis in this package analysed by Oksanen \& Minchin (1997), the analyses were redone with the same options with the program PC-ORD v. 3.05 (McCune \& Mefford 1997) - with slightly different results along the second axes. 
Table 1. Soil seed bank (mean \pm standard deviation and frequency, $n=20)$ and density of adult plants (mean \pm standard deviation and frequency, $n=10$ ) in spring censuses of two consecutive years. Soil samples had a diameter of $8 \mathrm{~cm}$ and a depth of $4 \mathrm{~cm}$; adult plants were censused in $10 \mathrm{~cm} \times 10 \mathrm{~cm}$ quadrats.

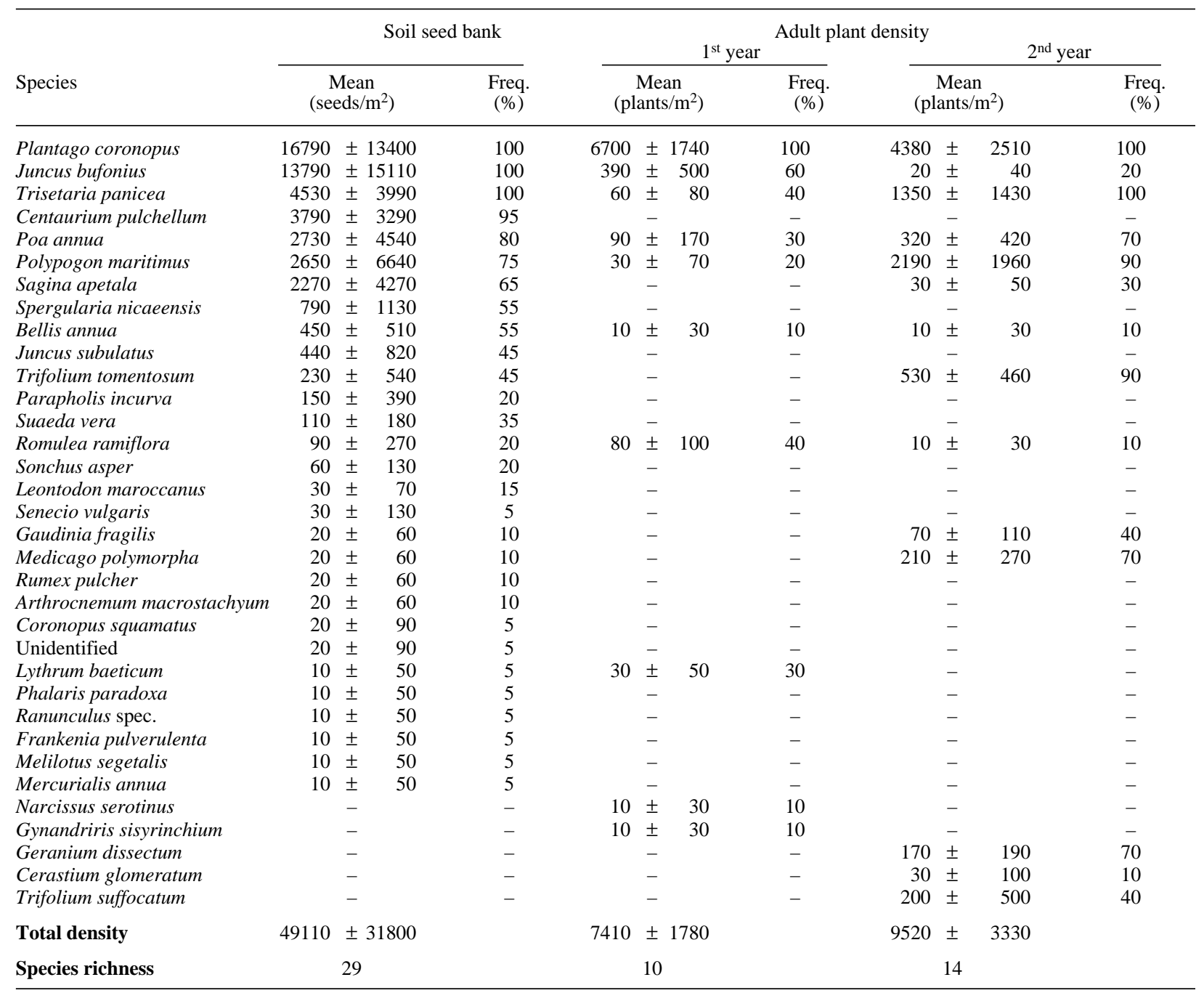

\section{Results}

\section{Soil seed bank}

On average 49110 seeds $/ \mathrm{m}^{2}$ were found in the soil and litter of the annual salt-marsh grassland. Three annual species were recorded in all the samples, and together made up more than $70 \%$ of the seed reserve: Plantago coronopus (34\%), Juncus bufonius (28\%) and Trisetaria panicea $(9 \%)$. Other frequent and abundant species in the seed bank, were Centaurium pulchellum (8\%), Роа аппиа (6\%) and Polypogon maritimus (5\%). Up to 29 species were recorded in the soil seed bank of the annual salt-marsh grassland, most of them in low density (Table 1).

\section{Field censuses of adult plants}

Field censuses in spring accounted for an average of 7410 plants $/ \mathrm{m}^{2}$, belonging to 10 different species. In the following year, 9520 plants $/ \mathrm{m}^{2}$ of 14 species were counted (Table 1).

There are both similarities and differences between the field censuses of adult plants in spring and the seed bank calculated in the soil the previous autumn. Plantago coronopus was the most abundant species in the adult plant community of both years $(90 \%$ and $46 \%$, respectively), and in the soil seed reserve (34\%). Three annual grasses, Trisetaria panicea, Poa annua and Polypogon maritimus were also abundant in the field censuses (but only in the second year), as well as in the 


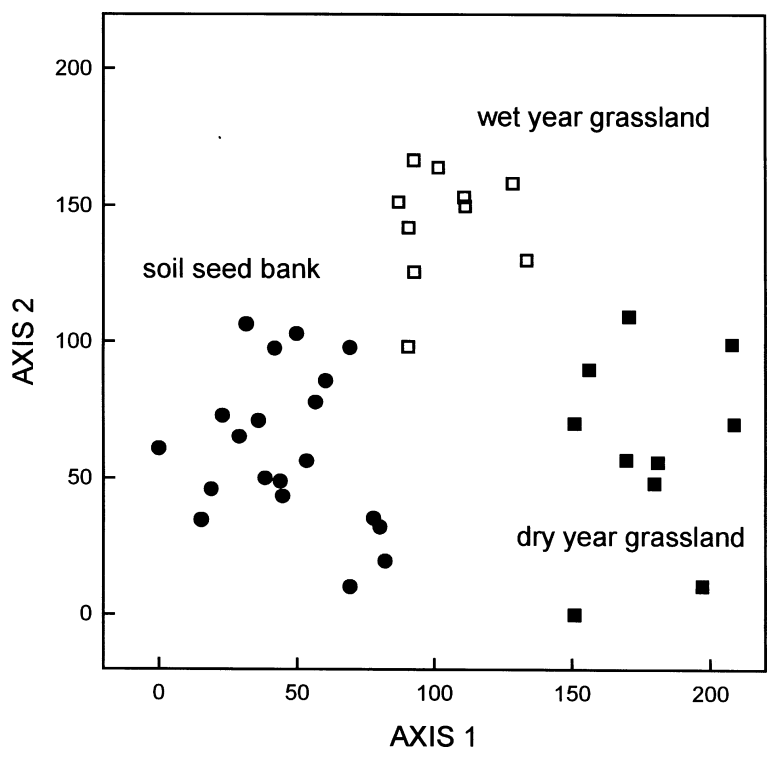

Fig. 2. Correspondence Analysis diagram of (autumn) soil seed bank (๑), and plant censuses in the first ( $\square$ ) and second ( $\square$ ) following springs.

seed bank. However, five species recorded in the spring censuses were not found in the soil samples: two geophytes, Narcissus serotinus and Gynandriris sisyrinchium, and three annuals, Geranium dissectum, Cerastium glomeratum and Trifolium suffocatum.

On the other hand, 17 species found in the seed bank were not recorded in the spring censuses of reproductive

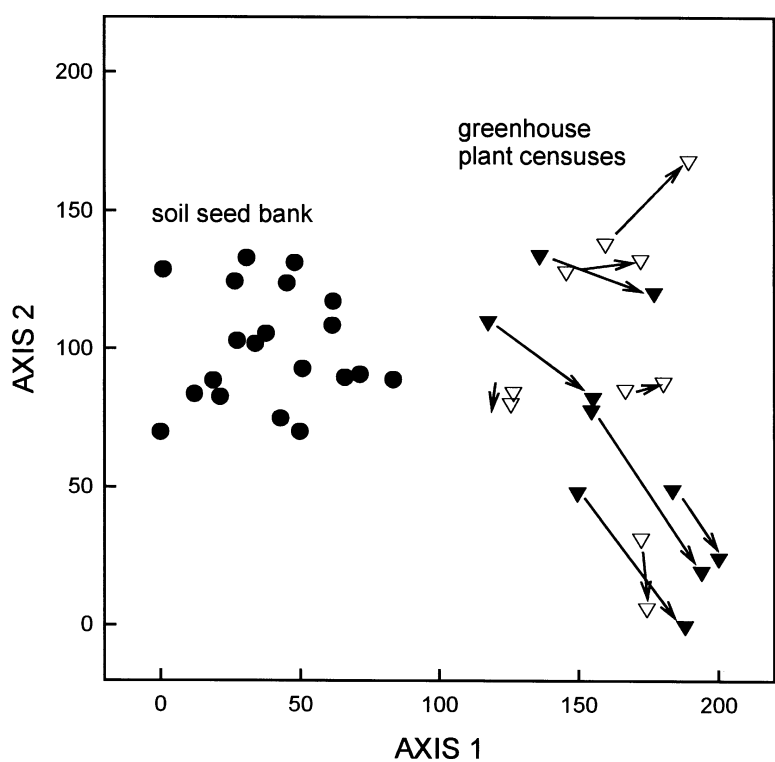

Fig. 3. CA ordination diagram of soil seed bank samples (๑), and plant censuses in transplanted soil blocks, subjected to salinity $(\nabla)$ and control $(\boldsymbol{\nabla})$ treatments. Arrows link pairs of censuses, from juvenile to reproductive stages. plants. Five of them were relatively frequent in the soil samples $(\geq 20 \%)$ : the annuals Centaurium pulchellum (very abundant), Spergularia nicaeensis, Parapholis incurva and Sonchus asper, and the perennials Juncus subulatus (a tall sedge very abundant in the lower salt marsh) and Suaeda vera (abundant as scattered bushes). The annual Juncus bufonius was very abundant in the soil samples, but rare in the spring censuses.

Overall, the similarities between the species composition in the seed bank and that of the adult plant censuses for the two years were low (Sørensen similarity indices of 41 and $51 \%$ respectively).

\section{Community dynamics}

There were remarkable changes in grassland species composition and plant density between the two consecutive springs (Table 1); accordingly the between-years similarity index was relatively low $(S=58 \%)$. The combined CA separated the seed bank samples towards the negative end of the first axis (eigenvalue $=0.26$ ). The second axis (eigenvalue $=0.11$ ) differentiated between the samples of plant density in the first (wet) and second (dry) years (Fig. 2).

Species associated to the wet year censuses (highest positive scores for axis 2) were Lythrum baeticum, and the bulbous Romulea ramiflora, Narcissus serotinus and Gynandriris sisyrinchium. Those associated to the dry year censuses (with the highest positive scores for axis 1) were Gaudinia fragilis, and the annual legumes Medicago polymorpha, Trifolium tomentosum and T. suffocatum.

The seed bank samples were associated to a large group of 17 species (with high negative scores for axis 1), which did not appear in either of the spring censuses of reproductive plants.

\section{Salinity effects on the transplanted seed bank}

A total of 1317 seedlings of 18 species emerged in the $101-\mathrm{dm}^{2}$ quadrats fixed in the transplanted soil blocks, under greenhouse conditions, but only 644 adult plants $(49 \%)$ of 11 species survived into the reproductive stage in the same quadrats.

The salinity treatment did not significantly affect the species number and seedling density in the early population stages. However, the long-term addition of a $\mathrm{NaCl}$ solution reduced the community biomass somewhat (ANOVA, $P=0.059$ ), when compared to control samples (Table 2).

Salinity had contrasting effects on the two co-dominant species: it reduced the growth of Trisetaria panicea significantly $(P=0.031)$, but increased the performance of Plantago coronopus slightly $(P=0.056$, Table 2$)$. 
Table 2. Salinity effects on species richness, plant density and biomass, in transplanted soil blocks in greenhouse conditions. Mean values \pm standard deviation $(N=5)$, and $F$ - and $P$-values of the ANOVA are indicated.

\begin{tabular}{|c|c|c|c|c|c|c|}
\hline \multicolumn{7}{|c|}{ Treatment } \\
\hline & \multicolumn{2}{|c|}{$\begin{array}{c}\text { Control } \\
\text { Mean } \pm \text { sd }\end{array}$} & \multicolumn{2}{|c|}{$\begin{array}{r}\text { Salinized } \\
\text { Mean } \pm \text { sd }\end{array}$} & $F$ & $P$ \\
\hline \multirow{2}{*}{\multicolumn{7}{|c|}{ Species richness (no./ $\mathrm{dm}^{2}$ ) }} \\
\hline & & & & & & \\
\hline seealmng stage & $5.6 \pm$ & 1.1 & $7.4 \pm$ & 2.0 & 3.176 & 0.113 \\
\hline $\begin{array}{l}\text { Reproductive plant stage } \\
\text { Density }\left(\text { no. } / \mathrm{m}^{2}\right)\end{array}$ & $2.8 \pm$ & 1.1 & $4.4 \pm$ & 1.3 & 4.267 & 0.073 \\
\hline \multicolumn{7}{|l|}{ Density $\left(\right.$ no. $\left./ \mathrm{m}^{2}\right)$} \\
\hline Seedling stage & $14280 \pm$ & 4950 & $12060 \pm$ & 5630 & 0.438 & 0.527 \\
\hline \multicolumn{7}{|c|}{ Aboveground biomass $\left(\mathrm{kg} / \mathrm{m}^{2}\right)$} \\
\hline Reproductive plant stage & $1.07 \pm$ & 0.33 & $0.72 \pm$ & 0.13 & 4.840 & 0.059 \\
\hline \multicolumn{7}{|l|}{ Dominant species } \\
\hline \multicolumn{7}{|l|}{ Seedling density (no. $\left./ \mathrm{m}^{2}\right)$} \\
\hline Plantago coronopus & $5860 \pm$ & 2530 & $6260 \pm$ & 4490 & 0.030 & 0.866 \\
\hline Trisetaria panicea & $7780 \pm$ & 6910 & $4680 \pm$ & 4250 & 0.730 & 0.418 \\
\hline \multicolumn{7}{|c|}{ Reproductive plant density (no./m²) } \\
\hline Plantago coronopus & $1100 \pm$ & 1060 & $2080 \pm \pm$ & 1750 & 1.154 & 0.314 \\
\hline Trisetaria panicea & $5280 \pm$ & 4000 & $3720 \pm$ & 3910 & 0.389 & 0.550 \\
\hline \multicolumn{7}{|l|}{ Population biomass $\left(\mathrm{kg} / \mathrm{m}^{2}\right)$} \\
\hline Plantago coronopus & $0.14 \pm$ & 0.16 & $0.35 \pm$ & 0.13 & 4.967 & 0.056 \\
\hline Trisetaria panicea & $0.85 \pm$ & 0.47 & $0.24 \pm$ & 0.24 & 6.827 & 0.031 \\
\hline
\end{tabular}

In the diagram of the first two CA-axes (Fig. 3) the seed bank samples are separated from the plant censuses in the transplanted soil by the first axis (eigenvalue $=0.31$ ), which also reflects a temporal variation from juvenile to reproductive stages. Additionally, the second axis (eigenvalue $=0.11$ ) reflects a divergence among saline and control samples; adult plant censuses of control blocks tend to be towards the negative end whereas those from saline blocks are towards the positive end.

\section{Discussion}

\section{Soil seed bank of Mediterranean grasslands}

Annual-dominated grasslands on the upper salt marsh are a particular type of more widespread Mediterranean grassland. They are affected mainly by summer drought stress, but also by episodic flooding in wet years and by a background of moderate salinity stress. The seed bank determined in this study (a first account for this vegetation type, as far as known) shows a general pattern, common to other Mediterranean grasslands, but with some peculiarities (Table 3 and references therein).

Table 3. Comparison between the soil seedbank of the saltmarsh grassland studied, with examples of other Mediterranean grasslands.

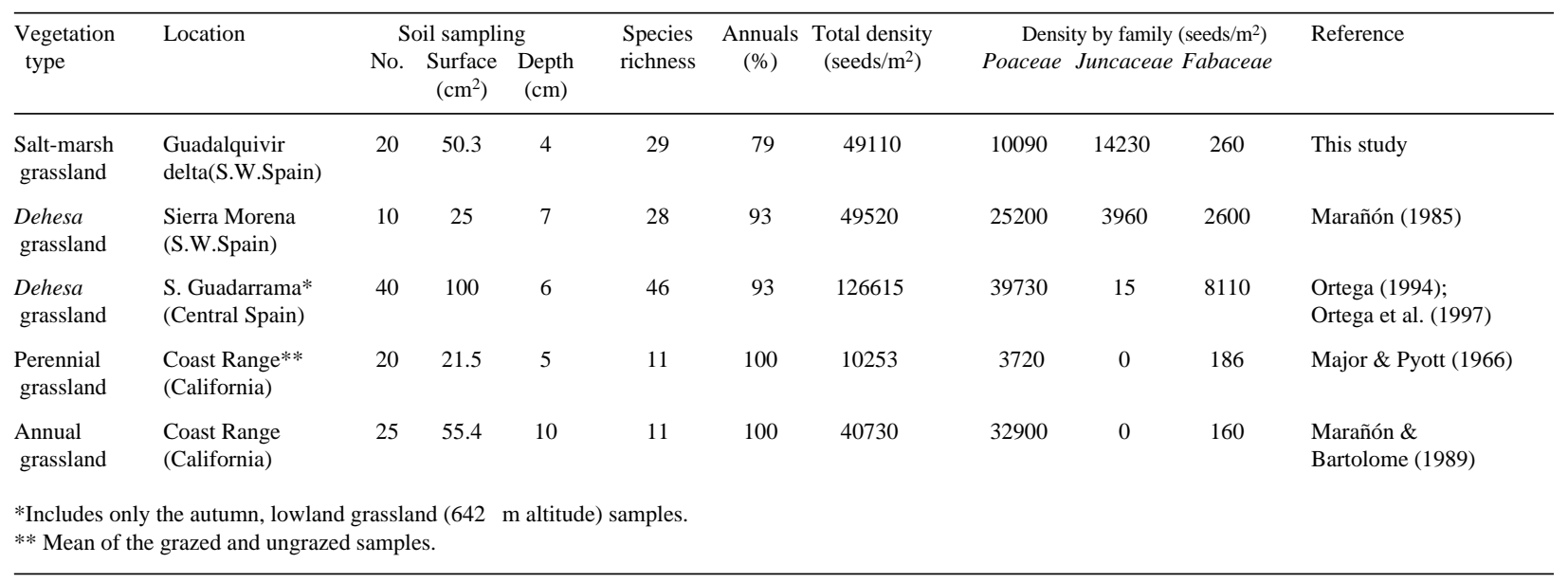


1. They are dominated by annual species, 80-100\%.

2. The total amount of germinable seeds in the soil, at the beginning of the rainy season, is relatively high (ca. 49000 seeds $/ \mathrm{m}^{2}$ ), which is comparable to a dehesa grassland in SW Spain and an oak savanna grassland in California (Table 1). It is higher than a perennial grassland with Stipa pulchra in California - and a temperate grassland in England (McDonald et al. 1996) - but lower than a Central Spanish dehesa, where a seed bank dominated by tiny seeds of Polycarpon tetraphyllum and Vulpia spp. contained up to $126600 \mathrm{seeds} / \mathrm{m}^{2}$.

3. Many species coexist in these annual communities. The species richness is relatively high in the Iberian seed bank samples (29-46 species) and lower in the Californian samples (11 species).

4. Seeds of grasses make up a large proportion of the soil seed bank of the grasslands mentioned: $20 \%$ in this salt marsh, $31-51 \%$ in the dehesa grasslands, and 36-81\% in the Californian grasslands.

5. The annual Juncus bufonius is the second most abundant species in this salt-marsh grassland $(28 \%$ of the seed bank); also significant is the presence, albeit in low densities, of the amphibious perennial Juncus subulatus. Annual rush seeds were also abundant in a dehesa of SW Spain, but they were rare in Central Spain. Juncus bufonius produces a large number of tiny seeds that persist in the soil seed bank; this species is 17 th in order of mean density $\left(5083 \mathrm{seeds} / \mathrm{m}^{2}\right.$, with a maximum of 89 063) at a depth of $0-10 \mathrm{~cm}$, in the NW European seed bank database (Thompson et al. 1997).

6 . Annual legumes were not abundant in the salt marsh $\left(260 \mathrm{seeds} / \mathrm{m}^{2}\right)$, unlike in the dehesa grasslands (2600 $8100 \mathrm{seeds} / \mathrm{m}^{2}$ ). Soil salinity may affect the germination and growth of the relatively salt-sensitive legumes (Läuchli 1984); however, some Mediterranean annual legumes, such as Melilotus segetalis, have developed a moderate resistance to salinity (Marañón et al. 1989a).

The species composition of the soil seed bank, in annual-dominated grasslands, tends to resemble the adult plant stage (Bartolome 1979; Marañón \& Bartolome 1989; Levassor et al. 1990; Ortega et al. 1997). In contrast, in temperate perennial grasslands, dominant species (usually with vegetative propagation) are rarely present in the soil seed bank (Thompson 1992). In the salt-marsh grassland the similarity between seed bank and adult plant stages was low, but the dominant species in the latter were always abundant in the former, unlike in perennial grasslands. The seed bank contained seeds of species expanding in either a wet or a dry year, and of many others which did not find suitable conditions during the study period. It is like a 'memory' of the fluctuations in seed rain during the recent past, and a source for regeneration in the unpredictable future.

\section{Seed bank and community dynamics}

Every spring, the community composition (at the reproductive stage) of the annual grassland is a different 'expression' of an ample soil seed reserve, mediated by climatic circumstances during germination, seedling establishment and growth, plant interference and survival from pathogens and predators.

During the wet year (an infrequent occasion), heavy rains caused a temporary flooding of the study area followed by a short growing season, interrupted by the summer drought period. That spring, the sparse grassland was composed of small plants of Plantago coronopus, mixed with Juncus bufonius and Lythrum baeticum (indicators of ephemeral wet conditions), and the bulbous Romulea ramiflora, Narcissus serotinus and Gynandriris sisyrinchium (which resisted flooding). In the following year, moderate rains in autumn and winter favoured a productive grassland, composed of annual grasses, (Trisetaria panicea and Polypogon maritimus), annual legumes (Medicago polymorpha, Trifolium tomentosum and T. suffocatum), and the common Plantago coronopus.

The large reservoir of seeds in the soil secures the populations of annual plants against adverse years, relatively frequent in the Mediterranean climate. For example, in the salt marsh studied, annual legumes were sensitive to flooding (probably dying at the seedling stage) and did not set seeds in the wet year; however new seedlings emerged from the persistent seed bank, grew and produced abundant seeds during the dry (not flooded) year. In contrast, Lythrum baeticum emerged and reproduced during the wet year, but not in the dry year (probably soil conditions did not fit its germination requirements). As a result, populations of contrasting ecological requirements are maintained in the same site, given a fluctuating environment, by the temporal mass effect (Shmida \& Ellner 1984).

In a review of seed banks from temperate European grasslands, Bekker et al. (1997) found that none of those grasslands studied had large proportions of species with a long-term persistent seed bank, which made it impossible to restore them from the soil seed bank. We need a precise evaluation of long-term longevity of seeds (beyond this two-years study) to predict the ability of Mediterranean salt-marsh grasslands to cope with environmental and human-induced changes.

\section{Salinity and competition: an experimental approach}

In general, the favourable conditions in the greenhouse (water availability, good drainage, lack of frost and exclusion of herbivores) promoted the growth of more productive plants, such as Trisetaria panicea and Plantago coronopus, which dominated other species. Species 
richness decreased from 18 species at the juvenile stage to 11 species in the reproductive stage. Among the seven species which were sensitive to overcrowding and did not reproduce, were the annual legumes Trifolium tomentosum and Medicago polymorpha. A light to moderate grazing pressure would reduce the dominance of the annual grass Trisetaria panicea and thus would maintain a higher species diversity. Bakker \& de Vries (1992) found a beneficial effect of grazing on the establishment of salt-marsh species.

The salinity treatment did not affect the emergence of seedlings. Seeds buried in this moderately saline soil must be relatively salt-tolerant in the germination stage, and therefore not be affected by addition of $\mathrm{NaCl}$. Moreover, salt tolerance during germination may occur in many glycophytes and halophytes, and does not always correlate with tolerance in later stages. For example, seeds of Juncus bufonius from a non-saline habitat achieved $53 \%$ germination in saline (50\% sea water), flooded conditions (Rozema 1975). However, salinity did reduce the growth of the dominant grass, Trisetaria panicea, and indirectly released its competitive pressure.

\section{Biodiversity and conservation}

Most of the biodiversity recorded in this herbaceous community is 'buried' in the soil: 29 species in the seed bank, versus 17 species inventoried in the vegetation during two consecutive years. The accumulation of seeds of such a variety of species in the soil is a memory of past episodes, sometimes of contrasting environmental conditions, favouring growth and seed production of different populations and genotypes (Baker 1989).

The fluctuating environment is therefore a source of variability, recorded in the seed bank, and a factor causing the high biodiversity of this grassland. Modifications of the physical environment in the Guadalquivir delta, leading to the reduction or elimination of these fluctuations (for instance building drainage channels or regulating water discharge), will impoverish the biodiversity of this dynamic community. Control of the water-level, based on the knowledge of seed banks, may be used for vegetation management; for instance, managers regulate flooding in North-American wetlands to recruit desirable species from the seed bank (van der Valk 1981; van der Valk \& Pederson 1989).

The dominance of Trisetaria panicea, as shown in the dry year field censuses and the non-saline soil blocks in the greenhouse, may indicate a process of desalinization of the upper salt marsh. This annual grass has a ruderal habit in SW Spain (Valdés et al. 1987) and has been expanding in the Guadalquivir salt-marsh grasslands during recent years, probably as a result of more fresh water entering from streams and less brackish water entering from the estuary, controlled by floodgates (L.V. García pers. com.). Such a process of 'ruderalization' may, in the long term, replace the peculiar herbaceous community of the upper salt marsh (described as Hainardio cylindricae-Lophochloetum hispidae by Rivas Martínez et al. 1980), and hence cause a biodiversity loss and a decline of salt-tolerant plant genetic resources (Marañón et al. 1989b).

Conservation managers will need basic information on the seed bank composition, seed longevity and germination requirements, of both preferred and undesirable species, to manipulate environmental conditions in the field, and in doing so, stimulate or impede the germination and establishment of target species (van der Valk \& Pederson 1989).

Acknowledgements. Thanks are due to L.V. García, J. Cara and A. Moreno for help with the field sampling and J.M. Romero with the greenhouse experiments, and to L.V. García, B. Peco, M.E. Figueroa, A. Huiskes and J.P. Bakker for their comments on the manuscript.

\section{References}

Baker, H.G. 1989. Some aspects of the Natural History of seed banks. In: Leck, M.A., Parker, V.T. \& Simpson, R.L. (eds.) Ecology of soil seed banks, pp. 9-21. Academic Press, San Diego, CA.

Bakker, J.P. \& de Vries, Y. 1992. Germination and early establishment of lower salt-marsh species in grazed and mown salt marsh. J. Veg. Sci. 3: 247-252.

Bartolome, J.W. 1979. Germination and seedling establishment in California annual grassland. J. Ecol. 67: 273-281.

Bekker, R.M., Verweij, G.L., Smith, R.E.N., Reine, R., Bakker, J.P. \& Schneider, S. 1997. Soil seed banks in European grasslands: does land use affect regeneration perspectives? J. Appl. Ecol. 34: 1293-1310.

Clemente, L., García, L.V. \& Siljeström, P. In press. Mapa de suelos del Parque Nacional de Doñana. MAPA, Madrid.

Espigares, T. \& Peco, B. 1993. Mediterranean pasture dynamics: the role of germination. J. Veg. Sci. 4: 189-194.

Espigares, T. \& Peco, B. 1995. Mediterranean annual pasture dynamics: impact of autumn drought. J. Ecol. 83: 135142.

Figueroa, M.E. \& Davy, A.J. 1991. Response of Mediterranean grassland species to changing rainfall. J. Ecol. 79: 925-941.

García, L.V., Marañón, T., Moreno, A. \& Clemente, L. 1993. Above-ground biomass and species richness in a Mediterranean salt marsh. J. Veg. Sci. 4: 417-424.

Gauch, H.G. 1982. Multivariate analysis in community ecology. Cambridge University Press, Cambridge.

Läuchli, A. 1984. Salt exclusion: an adaptation of legumes for crops and pastures under saline conditions. In: Staples, R.C. \& Toenniessen, G.H. (eds.) Salinity tolerance in plants, pp. 171-187. Wiley Interscience, New York, NY. 
Levassor, C., Ortega, M. \& Peco, B. 1990. Seed bank dynamics of Mediterranean pastures subjected to mechanical disturbance. J. Veg. Sci. 1: 339-344.

Major, J. \& Pyott, W.T. 1966. Buried, viable seeds in two California bunchgrass sites and their bearing on the definition of a flora. Vegetatio 13: 253-282.

Marañón, T. 1985. Reserva de semillas en el suelo de una dehesa en Sierra Morena: relación con la vegetación. Anal. Edaf. Agrobiol. 44: 1805-1816.

Marañón, T. \& Bartolome, J.W. 1989. Seed and seedling populations in two contrasted communities: open grassland and oak (Quercus agrifolia) understory in California. Acta Oecol. Oecol. Plant. 10: 147-158.

Marañón, T. \& Bartolome, J.W. 1993. Reciprocal transplants of herbaceous communities between Quercus agrifolia woodland and adjacent grassland. J. Ecol. 81: 673-682.

Marañón, T., García, L.V. \& Troncoso, A. 1989a. Salinity and germination of annual Melilotus from the Guadalquivir delta (SW Spain). Plant \& Soil 119: 223-228.

Marañón, T., García, L.V., Murillo, J.M. \& Clemente, L. 1989b. Las marismas del Guadalquivir, reserva biogenética de plantas tolerantes a la salinidad. Anal. Edaf. Agrobiol. 48: 725-740.

McCune, B. \& Mefford, M.J. 1997. PC-ORD. Multivariate analysis of ecological data, version 3.05. MjM Software Design, Gleneden Beach, OR.

McDonald, A.W., Bakker, J.P. \& Vegelin, K. 1996. Seed bank classification and its importance for the restoration of species-rich flood-meadows. J. Veg. Sci. 7: 157-164.

Mueller-Dombois, D. \& Ellenberg, H. 1974. Aims and methods of vegetation ecology. John Wiley \& Sons, New York, NY.

Oksanen, J. \& Minchin, P.R. 1997. Instability of ordination results under changes in input data order: explanations and remedies. J. Veg. Sci. 8: 447-454.

Ortega, M. 1994. Papel de los bancos de semillas en pastizales mediterráneos: variabilidad espacio-temporal y respuestas al abandono del pastoreo. Ph. D. Dissertation, Universidad
Autónoma de Madrid

Ortega, M., Levassor, C. \& Peco, B. 1997. Seasonal dynamics of Mediterranean pasture seed banks along environmental gradients. J. Biogeogr. 24: 177-195.

Peco, B. 1989. Modelling Mediterranean pasture dynamics. Vegetatio 83: 269-276.

Rivas-Martínez, S., Costa, M., Castroviejo, S. \& Valdés, E. 1980. Vegetación de Doñana (Huelva, España). Lazaroa 2: 5-189.

Rozema, J. 1975. The influence of salinity, inundation and temperature on the germination of some halophytes and non-halophytes. Oecol. Plant. 10: 341-353.

Shmida, A. \& Ellner, S. 1984. Coexistence of plant species with similar niches. Vegetatio 58: 29-55.

Soriguer, R.C., Delibes Senna, J.R., Zamora, R. \& Fandos, P. 1994. Evaluación de la capacidad de carga de la marisma del Parque Nacional de Doñana. CSIC-ICONA Report, Sevilla.

ter Braak, C.J.F. 1988. CANOCO. GLW Techn. Rep., Wageningen.

Thompson, K. 1992. The functional ecology of seed banks. In: Fenner, M. (ed.) Seeds. The ecology of regeneration in plant communities, pp. 231-258. CAB International, Wallingford.

Thompson, K., Bakker, J.P. \& Bekker, R.M. 1997. The soil seed banks of North West Europe. Cambridge University Press, Cambridge.

Valdés, B., Talavera, S. \& Galiano, E.F. 1987. Flora vascular de Andalucía occidental. 3 Vols. Ketres, Barcelona.

van der Valk, A.G. 1981. Succession in wetlands: a Gleasonian approach. Ecology 62: 688-696.

van der Valk, A.G. \& Pederson, R.L. 1989. Seed banks and the management and restoration of natural vegetation. In: Leck, M.A., Parker, V.T. \& Simpson, R.L. (eds.) Ecology of soil seed banks, pp. 329-346. Academic Press, San Diego, CA.
Received 12 September 1997; Revision received 12 February 1998; Accepted 12 March 1998. 